\title{
Minor (Under-utilized) Fruits in Coochbehar District of West Bengal, India- an Analysis on Marketing Status for Economic Viability
}

\author{
Tuhin Narayan Roy* \\ Department of Agricultural Economics, UBKV, P.O. Pundibari, Coochbehar district, West Bengal (736 165), India
}

\section{Article History}

Manuscript No. cn4

Received in $8^{\text {th }}$ January, 2013

Received in revised form $12^{\text {th }}$ February, 2014

Accepted in final form $5^{\text {th }}$ March, 2014

\section{Correspondence to}

"E-mail: tuhinnroy@rediffmail.com

\section{Keywords}

Minor fruits, marketing, supply chain, constraints, strategies

\begin{abstract}
This paper is analytical in nature and presents the findings of a study carried out on primary information/data collected Coochbehar district of West Bengal during 2010-11 on marketing of minor (under-utilized) fruits in order to find out the status of marketing and to suggest suitable marketing strategies for viable economic proposition. Major fruits are cultivated in most tropical (and subtropical) countries for both local and international markets. Minor fruits have limited cultivation, consumption and trade. Coochbehar district of West contributes about 33\% major and minor fruits. Marketing remains a big problem for these fruits qualitatively and quantitatively. Most of the minor fruits are season-bound, scattered in distribution, marketed in fresh form but marketed surplus is insignificant, though the market prices are high in absence of definite channels (supply chain), set pattern of pricing and prescribed standards for grading. High risk factors and investment costs discourage the private entrepreneurs for investment. Some constraints of marketing are lack of reliable statistical data, consumers' ignorance, long gestation period, mode of storage and ripening and absence of post harvest operations (processing). Generation of awareness about economic, nutritional and environmental values, identification of potential minor fruits, adoption of improved cultivation and appropriate post-harvest technology, provision of standardization of production technology, mobilization/formation of local entrepreneurs, analysis of buyers' and sellers' perceptions and behaviours, govt. policy to support a source of income as well as minor fruits cultivation are some of the recommendations.
\end{abstract}

\section{Introduction}

The paper is analytical in nature based on both primary and secondary sources of information and the purpose of this study is to identify the underutilized fruits in the area, the constraining factors, and assess the potentiality with special reference to marketing. Minor (Underutilized) species are defined in different ways such as minor, traditional, neglected, new, alternative, lost, orphan, promising, underdeveloped etc. Beside their importance for nutritional value and a source of income, diversity of these fruits also has a cultural and social value and contributes to the stability of ecosystems (Arora, 1998). Minor fruits are not so extensively cultivated, and their consumption and trade remain to be more limited. However, many are of considerable economic importance in their respective regional markets (Anang and Chan, 1999).

Minor fruits are characterized by the fact that (i) they are locally abundant, but restricted in their geographical dispersion with a high use value, (ii) they are widely adaptable to agro-ecological niches/marginal areas, (iii) it lacks scientific knowledge about them, and (iv) their current use is limited relative to their economic potential. Some negative aspects of these crops are also recorded like poor documentation (particularly on their distribution, biology, cultivation needs, uses etc.), almost nonexistent or poorly organized marketing system (production-touse chain), relying on Indigenous Knowledge which receives little attention in institutional policies, R\&D etc.

In India, about $27 \%$ of the fruit production consists of a large number of minor fruits. There are nearly 150 of consumable species of minor fruits in India (Majumder, 2004). Peter (2007) observed that cultivation of these fruits on a commercial scale is not yet attempted. Gandhi (2002) also analysed the issues of fruit marketing efficiency in India. The land holding pattern in West Bengal in general reveals that nearly $90 \%$ of the farmers are small and marginal; hence, the minor crops are ideal for cultivation because of their low input requirement, less production cost, higher nutritive value and high yield.

During 2007-08, in northern part of West Bengal about 0.91 
$\mathrm{mt}$ fruits were produced. In Coochbehar district, out of total area of 4560 ha under fruit crops, other fruits (including minor fruits) occupies only $310 \mathrm{ha}$. Some of the minor fruits are not acceptable in the market in fresh form due to their acidic nature and astringent taste. Hence, there is a need to concentrate on research efforts in diversification and popularization of such crops. And this could be possible to some extent through development of suitable processing and marketing strategies (Gajanan et al, 2010). Proper documentation and appropriate information about its commercial status are yet to be adequately obtained. However, considering the disordered presence and availability in the market, some common minor (under-utilized) fruits have been taken into consideration for this study with the following specific objectives such as; to identify potential minor (under-utilized) fruits, to examine the marketing system including opportunities and constraints, to study producers' perceptions towards these crops and marketing and to suggest strategies for efficient marketing of minor (under-utilized) fruits.

\section{Materials and Methods}

This is an analytical study based on primary as well as secondary information. The study has been carried out in the selected villages of two blocks in Coochbehar district of West Bengal during 2010-11. The area falls under the Terai Zone according to agro-climatic classification of West Bengal State'. Data for this study has been generated through key informant survey and individual household survey from 50 respondents by using semi-structured questionnaire and checklists during individual and group interviews. Key informants like agricultural extension agents, community opinion leaders and local peoples' representatives have been purposively selected and interviewed. Both quantitative and qualitative data have been collected on different aspects related to minor fruit marketing. Usual tabular analyses have been done for quantitative data. Simple mathematical tools like average, mean etc. have been followed. Qualitative data (respondents' perceptions) have been recorded and presented in tabular form for analysis. In case of scoring data, as obtained, have also been demonstrated in tabular form.

\section{Results and Discussion}

\subsection{Socio-economic characteristics of the respondents}

Information shows that underutilized fruits are grown mainly in marginal, sub-marginal or homestead land. Out of the sample size of the farmers interviewed, $41(82 \%)$ are males and 9 $(18 \%)$ belong to females. The average age of the respondents is about 43 years with the oldest being 70 years while the youngest being 19 years. Education level has been found to range from illiterate $(10 \%)$ to graduate $(2 \%)$. The average farm size is about 0.30 acres. About $52 \%$ of individual respondents have their own land and those whose farms are still owned by the family are $48 \%$.

\subsection{Type of fruits grown}

As shown in Table 1, farmers give a list of underutilized (minor) fruits. Some fruits such as : Golap Jam or Rose Apple (Eugenia jambos Linn./ Syzygium jambos), Jalpai or Indian olive, (Elaeocarpus floribundus)), Latka or Burmese grape (Baccaurea sapida) and Panial or Indian plum/Coffee plum (Flacourtia jangoma), Fig (Ficus carica), Ber or Indian jujube (Zyziphus mauritiana), Chalta or Elephant apple (Dillenia indica), Sofeda (Manilkara zapota), Bael (Aegle marmelos), Ata (Anona muricata), Jamrul (S. samarangense), Dalim (Punica granatum), Tamarind (Tamarindus indica), Jamun (Syzygium cumini), Papaya (Carica papaya), Kamranga (Averrhoa carambla), Aonla (Phyllanthus Emblica L., Papaya (Carica papaya etc. are grown or available in the respondents' farms in the locations of the study.

The table also shows the frequencies of distribution of different minor fruits. There remains a significant difference in the distribution of some fruits across two selected blocks though the number of plant is small. Frequencies of the fruits like Jamun, Bael, Ber, Papaya etc. are found more.

\subsection{Establishment of minor fruit plants}

Respondents' perceptions have been assessed with special reference to financial involvement and establishment of minor

Table 1: Respondents' list on underutilized (minor) fruits in coochbehar district (WB)

\begin{tabular}{llccc}
\hline S1. & Name of the minor fruits & \multicolumn{3}{c}{ Frequencies (No.) } \\
\cline { 3 - 5 } No. & & Block-I & Block-II & Total \\
\hline 1 & Rose Apple or Golap Jam & 2 & 3 & 5 \\
2 & Jalpai or Indian Olive & 4 & 8 & 12 \\
3 & Latka or Burmese Grape & 6 & 6 & 12 \\
4 & Panial or Indian Plum/Cof- & 5 & 2 & 7 \\
& fee Plum & & & \\
5 & Chalta or Elephant Apple & 8 & 10 & 18 \\
6 & Sofeda & 5 & 5 & 10 \\
7 & Jamrul & 5 & 9 & 14 \\
8 & Tamarind & 5 & 2 & 7 \\
9 & Jamun & 15 & 12 & 27 \\
10 & Aonla & 2 & 4 & 6 \\
11 & Dalim & 7 & 8 & 15 \\
12 & Kamranga & 5 & 6 & 11 \\
13 & Bael & 12 & 9 & 21 \\
14 & Ber or Indian Jujube & 15 & 13 & 28 \\
15 & Papaya & 11 & 17 & 28 \\
16 & Ata & 4 & 7 & 11 \\
\hline
\end{tabular}


fruit crops. The results of the findings are presented in Table 2.

According to respondents, majority of the minor fruit plants are obtained from the previous generations. Some believe to have these plants occurred naturally. Saplings procured from nursery or mela (fair) occupy $4^{\text {th }}$ position only. In respect of financial investment, majorities views go behind the low cost cultivation and family labour involvement which is followed by costless cultivation and low maintenance cost. Thus, it may be opined that scientific method of establishment/cultivation of minor fruit plants in commercial basis is lacking.

\subsection{Marketing status of minor fruits}

There is no market for minor fruits. These fruits are sold with the major fruits or separately with other crops. Most of the minor fruits are collected during the season and brought in small quantities to the local market including the time of some festivals/occasions. Since marketed surplus is scattered in nature, it follows no definite channels. There is no set pattern of pricing (sometimes season dependent) and weight and measure. No prescribed standards for grading of minor fruits depending upon their size, colour, weight etc. Earnings from marketing of minor fruits in this area serves only additional source of income. In absence of sufficient information, it remains a difficult task to arrive at some strategic points for marketing development. Poor efficiency in the marketing channels and inadequate marketing infrastructure are believed to be the cause of not only high and fluctuating consumer prices, but also to little of the consumer rupee reaching the farmer (Kaul, 1997). Table 3 shows the mode of disposal of underutilized (minor) fruits after harvesting as per the information received from the respondents.
The main uses for these fruits were identified as home consumption, home consumption and local markets. About $58 \%$ of these fruits are being consumed at home, $27 \%$ and $12 \%$ are combination of home consumption and local market and local market only respectively. However, some small amounts would find their way to the local markets but survey reveals that most of them go to waste due to damage by birds, theft and rotting (disease and pest).

\subsection{Marketing channel / supply chain}

Marketing channel describes the original routes of product movement from production point to ultimate consumption point. The Supply Chain is the management of a network of interconnected businesses involved in the ultimate provision of product and service required by the end customer. As per the information of the producers as well as the retailers, some marketing channels have been identified which are presented below in Table 4.

No channels are permanent in nature. However, Channel-I and Channel-II are found to be more effective as the gap between consumer price and producer price remains at minimum. In absence of any processing (post harvest operation), this system is considered to be comparatively more efficient as the producers get full share of consumer price. For others, only transportation cost and middlemen's profit margins are involved towards marketing cost. Except Channel-III \& IV, all other channels have lower marketing cost. In case of Channel-I, only transportation cost constitutes marketing cost. It is also estimated that marketing margin is higher in case of Channel-II, III and IV due to comparatively longer length of supply chain. Marketing Efficiency (ME) under different channels for sample minor fruits reveals zero marketing channel i.e. self-marketing

\begin{tabular}{|c|c|c|c|c|c|c|}
\hline A. Establishment of Plant & $\begin{array}{l}\text { Strongly } \\
\text { confirmed }\end{array}$ & $\begin{array}{l}\text { Moderately } \\
\text { confirmed }\end{array}$ & $\begin{array}{c}\text { Not } \\
\text { confirmed }\end{array}$ & Negative & Frequency & Rank \\
\hline i. Obtained from forefather & $* * * * *$ & $* * *$ & ** & * & 11 & $1^{\text {st }}$ \\
\hline ii. Naturally occurred & $* * *$ & $* * *$ & $* * *$ & - & 9 & $2^{\text {nd }}$ \\
\hline iii. From Mela /Nursery & $* * *$ & ** & ** & - & 7 & $4^{\text {th }}$ \\
\hline iv. Collected from the neighbour & $* * *$ & *** & - & - & 6 & $5^{\text {th }}$ \\
\hline v. Received as a gift & ** & ** & - & * & 4 & $7^{\text {th }}$ \\
\hline vi. Grown at homestead land & $* * * * *$ & ** & - & - & 8 & $3^{\text {rd }}$ \\
\hline vii. No specific field & $* * *$ & ** & - & - & 5 & $6^{\text {th }}$ \\
\hline \multicolumn{7}{|l|}{ B. Financial Investment } \\
\hline i. Low Cost of cultivation & $* * * * *$ & **** & * & - & 10 & $1^{\text {st }}$ \\
\hline ii. No cost of cultivation & $* * *$ & $* * *$ & * & ** & 9 & $2^{\text {nd }}$ \\
\hline iii. Low maintenance cost & $* * * *$ & $* *$ & ** & - & 8 & $3^{\text {rd }}$ \\
\hline iv. Family labour only & $* * *$ & $* * *$ & ** & ** & 10 & $1^{\mathrm{st}}$ \\
\hline v. Family plus Hired labour & ** & ** & * & - & 5 & $4^{\text {th }}$ \\
\hline vi. No cost involved & * & ** & ** & *** & 8 & $3^{\text {rd }}$ \\
\hline
\end{tabular}

*indicates increasing importance 
(Channel-I), may be considered to be most efficient. Since, there is no facility value-addition (processing), measurement of marketing efficiency may invite lot of questions. Rathore (2002) reported that marketing of underutilized fruit sector in India has no definite channels. The exact figure of marketing cost and share could not be estimated due to collective transportation cost with other agricultural produce.

\subsection{Comparative price of minor fruits at various situations}

It is evident that the price of fruits varied from market to market, source to source and area to area. Except self-marketing, fruits generally are sold at a rate which is lower than the market price. Some fruits are produced year round, but quantity remains very low. Those fruits which are marketed in the lean periods fetch higher price. According to respondents' experiences, the unit prices at production area, buying spot, selling spot and in lean season have been shown in Table 5. During the study few minor fruit species like Tamarind, Batabi Lebu, Bael, Aonla etc. were found available in lean period which have been presented in the same table.

\subsection{Facilities of minor fruits processing}

The survey results do not provide any information about the facilities for value addition through the post-harvest operations or processing. Due to non-availability of any facilities or infrastructure or knowledge, majority of the respondents have expressed very little level of awareness about this technology. This information may guide policy makers/investors to chalk out strategy for development.

\subsection{Constraints of marketing of minor fruit crops (based on} respondents'perceptions)

Findings from survey reveal some problems and limitations which stand, in general, in the way of commercial exploitation (marketing) and development of minor fruits which are mentioned below.

- Non-availability of statistical data on minor fruits in general and marketing in particular.

- Absence of quality product due to non-availability of quality seeds/planting materials.

- Lack of awareness of both buyers and sellers about nutritional and economic value.

- Non-availability of processing, packaging, storage facilities leading to wastage.

- Absence of scientific resources for testing, valuation and post-harvest management.

- Negligible existence of the marketing network and infrastructure facility.

- Very low level of marketing functions due to financial constraints and market risk.

- Govt. as well as private sector yet to take major role to promote marketing.
- Risky business due to perishable in nature and unpredictable demand in the markets.

In fact, very small scale and scattered production accompanying by inconsistent supply due to seasonality keeps this business behind according to modern marketing concept.

On the basis of respondents' behavior and attitude frequencies on constraints as well as different aspects of marketing have been

Table 3: Mode of disposal of minor fruits after harvesting in Coochbehar district of West Bengal (Frequencies of responses by uses)

\begin{tabular}{|c|c|c|c|c|c|}
\hline $\begin{array}{l}\text { Fruit } \\
\text { Types }\end{array}$ & $\begin{array}{l}\text { Home } \\
\text { Con- } \\
\text { sump- } \\
\text { tion }\end{array}$ & $\begin{array}{l}\text { Home Con- } \\
\text { sumption } \\
\text { \& Local } \\
\text { Market }\end{array}$ & $\begin{array}{c}\text { Local } \\
\text { Mar- } \\
\text { ket }\end{array}$ & $\begin{array}{c}\text { Sales } \\
\text { in well } \\
\text { defined } \\
\text { market }\end{array}$ & Total \\
\hline Rose Apple & 2 & 1 & 2 & 0 & 5 \\
\hline Jalpai & 8 & 4 & 0 & 0 & 12 \\
\hline Latka & 10 & 2 & 0 & 0 & 12 \\
\hline Panial & 4 & 2 & 1 & 0 & 7 \\
\hline Chalta & 10 & 7 & 4 & 0 & 18 \\
\hline Sofeda & 4 & 3 & 0 & 2 & 10 \\
\hline Jamrul & 9 & 4 & 2 & 0 & 14 \\
\hline Tamarind & 0 & 5 & 0 & 2 & 7 \\
\hline Jamun & 9 & 3 & 3 & 0 & 15 \\
\hline Aonla* & 0 & 4 & 0 & 2 & 6 \\
\hline Kamranga & 8 & 2 & 1 & 0 & 11 \\
\hline Bael & 11 & 4 & 2 & 0 & 21 \\
\hline Ber & 20 & 5 & 3 & 0 & 28 \\
\hline Dalim & 8 & 3 & 4 & 0 & 15 \\
\hline Ata & 8 & 2 & 1 & 0 & 11 \\
\hline Total & $\begin{array}{c}111 \\
(58 \%)\end{array}$ & $52(27 \%)$ & $\begin{array}{c}23 \\
(12 \%)\end{array}$ & $6(3 \%)$ & $\begin{array}{c}192 \\
(100 \%)\end{array}$ \\
\hline
\end{tabular}

${ }^{*}$ Aonla (Amalaki) is treated as minor fruit in this area

Table 4: Marketing channels/ supply chains and ranking of marketing efficiency

\begin{tabular}{|c|c|c|}
\hline S1. No. & Channel/ supply chain & $\begin{array}{l}\text { Marketing } \\
\text { efficiency }^{*}\end{array}$ \\
\hline Channel-I & Producer $\rightarrow$ Consumer & $1^{\text {st }}$ \\
\hline Channel-II & $\begin{array}{l}\text { Producer } \rightarrow \text { Local assembler } \rightarrow \\
\text { Retailer } \rightarrow \text { Consumer }\end{array}$ & $3^{\text {rd }}$ \\
\hline $\begin{array}{l}\text { Channel- } \\
\text { III }\end{array}$ & $\begin{array}{l}\text { Producer } \rightarrow \text { Middlemen/ whole- } \\
\text { seller } \rightarrow \text { Retailer } \rightarrow \text { Consumer }\end{array}$ & $4^{\text {th }}$ \\
\hline $\begin{array}{l}\text { Channel- } \\
\text { IV }\end{array}$ & $\begin{array}{l}\text { Producer } \rightarrow \text { Middlemen/ trader/ } \\
\text { Processing unit } \rightarrow \text { Distributor } \rightarrow \\
\text { Retailer } \rightarrow \text { Consumer }\end{array}$ & $5^{\text {th }}$ \\
\hline Channel-V & $\begin{array}{l}\text { Producer } \rightarrow \text { Vendor / Hawker } / \\
\text { Roadside seller } \rightarrow \text { Consumer }\end{array}$ & $2^{\text {nd }}$ \\
\hline
\end{tabular}


recorded on the basis of respondents' perceptions (Table 6).

Respondents' perception reveals that lack of marketing facility is the main constraint which is followed by lack of govt. policy, lower return, inadequate knowledge etc. So, these issues again ask for appropriate attention from the policy makers. Sabbe (2009) has recorded same view in this direction for marketing strategy for minor fruits.

\subsection{Recommendations for development of optimum production and marketing}

Gajanana (2010) showed that economic analysis of small scale processing of underutilized fruits were profitable. Based on survey results, specific recommendations have been put below:
- Identification of minor fruits for commercial purpose may be done and maintain their documentation for future reference.

- Linkages between small and marginal farmers on one side and the retail sector on the other side needs to be developed (Reddy, 2010) and linked with other crops..

- Multi-product fruits processing may be encouraged with PPP model and easy credit facility.

- Institutional efforts are necessary for providing technical, financial and marketing support by the Govt., NGOs, financial institutions, private traders etc.

- Role of agricultural research should not be undermined (Birthal, 2008).

Table 5: Comparative price of minor fruits at various situations

\begin{tabular}{|c|c|c|c|c|c|c|}
\hline Sl. No. & Minor fruits (Local name) & Unit & Unit price at buying & Unit selling price & Unit price in Lean period & $\begin{array}{l}\text { Increase in lean } \\
\text { season }(\%)\end{array}$ \\
\hline 1. & Jalpai & $\mathrm{Kg}$ & 20 & 30 & - & - \\
\hline 2. & Latka & $\mathrm{Kg}$ & $8-10$ & $15-18$ & - & - \\
\hline 3. & Golap jam & $\mathrm{Kg}$ & $60-70$ & $100-120$ & - & - \\
\hline 4. & Jam & $\mathrm{kg}$ & 40 & $60-80$ & - & - \\
\hline 5. & Khejur & $\mathrm{kg}$ & $15.00-20.00$ & $20.00-30.00$ & - & - \\
\hline 6. & Chalta & No. & $2.00-2.50$ & $4.00-5.00$ & - & - \\
\hline 7. & Tamarind / tetul & $\mathrm{Kg}$. & $30.00-40.00$ & $40.00-50.00$ & $60.00-70.00$ & 50.00 \\
\hline 8. & Batabi lebu & No. & $6.00-7.00$ & $10.00-12.00$ & $16.00-20.00$ & 60.00 \\
\hline 9. & Ata & No. & 10.00 & 10.00 & - & - \\
\hline 10. & Safeda & $\mathrm{Kg}$. & 20.00 & $25.00-30.00$ & - & - \\
\hline 11. & Ber/ kul & $\mathrm{Kg}$. & 25.00 & $35.00-40.00$ & $70.00-80.00$ & 100.00 \\
\hline 12. & Jamrul & $\mathrm{Kg}$. & 30.00 & $50.00-60.00$ & - & - \\
\hline 13. & Bael & No. & $5.00-6.00$ & $8.00-10.00$ & $12.00-15.00$ & 50.00 \\
\hline 14. & Kamranga & $\mathrm{Kg}$. & $25.00-30.00$ & 40.00 & - & - \\
\hline 15 & Amaloki & Kg. & $25.00-30.00$ & $40.00-50.00$ & $80.00-100.00$ & 100.00 \\
\hline
\end{tabular}

Table 6: Assessment of constraints in the promotion of marketing of minor fruits (underutilized) (respondents' perception in frequencies)

\begin{tabular}{lcccccc}
\hline \multirow{2}{*}{ Constraints } & \multicolumn{3}{c}{ Importance } & Total frequencies & Rank \\
\cline { 2 - 4 } & Most & Less & No opinion & & \\
\hline Low competitiveness & 40 & 8 & 2 & 48 & 2 nd \\
Lack of knowledge on uses & 36 & 10 & - & 46 & 3 rd \\
Low income & 48 & 2 & - & 50 & $1^{\text {st }}$ \\
No processing facilities & 30 & 13 & 2 & 43 & 4 th \\
Lack of marketing facility / poor commercialisation & 49 & 1 & - & 50 & $1^{\text {st }}$ \\
Loss of traditional knowledge & 31 & 8 & - & 39 & 5 th \\
Lack of policy & 50 & - & - & 50 & 1 st \\
Lack of research on assessment and use & 15 & 10 & - & 25 & 8 th \\
Lack of propagation techniques & 30 & 3 & - & 33 & 6 th \\
Scarce knowledge on cultural practices & 18 & 14 & - & 32 & 7 th \\
Lack of attractive traits & 15 & 10 & - & 25 & 8 th \\
\hline
\end{tabular}


SWOT (strength, weakness, opportunity and threat) analysis of marketing management concept could be conducted which may help to prepare appropriate production and marketing strategies.

\section{Conclusion}

Marketing of minor fruits has lot of limitation in the area under study. Commercial opportunities may be obtained through appropriate strategy in production and marketing. Proper documentation and awareness about the benefits of minor fruits should be promoted. Application of modern marketing management concept may promote selling of minor fruits which should be adequately supported by infrastructural and institutional arrangements. The holistic approach may ideally be multidimensional through a concerted effort which will include a large number of stakeholders (research institution, Govt., NGOs, private, credit institutions etc.) and making use of participatory methods. This will motivate the rural people to grow more minor fruits for additional income. So, it is suggested to invest more on research efforts for popularization of such crops through suitable production, processing and marketing strategies.

\section{References}

Anang and Chang, 1999. Tropical and Subtropical Fruit. Available from http://www.enotes.com.

Arora, R.K., 1998. Promoting conservation and use of tropical fruit species in Asia. Available from http://www2. bioversityinternational.org

Birthal, P.S., Joshi, P.K., Chauhan,S., Singh, H., 2008 Can
Horticulture Revitalized Agricultural Growth ? Indian Journal of Agricultural Economics 63(3), 310-321.

Gajanan, T.M., 2010. Exploring Market Potential and Developing Linkages- a case study of underutilized fruit products in India. Agricultural Economics Research Review 23, 437-443.

Gandhi, V.P., Namboodiri, N.V., 2002. Fruits and vegetables marketing and its efficiency in india : a study of wholesale markets in the ahmedabad area, IIM, Ahmedabad, India, June. Available from 205.186.138.171/assets/ snippets/...2002-12-05vasantgandhi.pdf,

Majumder, B.C., 2004. Minor fruit crops of India - tropical and sub-tropical. Daya Publishing House, New Delhi.

Peter, K.V. 2007. Under-utilized and under-exploited horticultural crops. New India Publishing House, New Delhi.

Rathore, D.S., 2002. Processing and Marketing of underutilized fruits in India. In: Haque, N., Huges, A. (Eds.), ICUC, Southampton, UK, 134-152.

Reddy, G.P., 2010. Value chains and retailing of fresh vegetables and fruits, andhra pradesh, Agricultural Economics Research Review 23, 455-460.

Sabbe, S., 2009. Consumer perception and behaviour towards tropical fruits in Belgium. $\mathrm{PhD}$ thesis. Faculty of Bioscience Engineering, University of Ghent, Belgium.

Senam Raju, M.S., 2002. Fruit marketing in India. Daya Publishing House, New Delhi. 